\title{
Are there differences in oxidative stress and inflammatory processes between the autogenous and reactive subtypes of obsessive-compulsive disorder? A controlled cross- sectional study
}

\author{
Melis Danışman Sonkurt, ${ }^{1}$ iD Ali E. Altınöz, ${ }^{2}$ iD Ferdi Köşger, ${ }^{2}$ Semra Yiğitaslan, ${ }^{3}$ Gülcan Güleç, ${ }^{2}$ \\ Altan Eşsizoğlu ${ }^{4}$ \\ ${ }^{1}$ Department of Psychiatry, Faculty of Medicine, Ağrı Training and Research Hospital, Ağrı, Turkey. ${ }^{2}$ Department of Psychiatry, Faculty of \\ Medicine, Eskişehir Osmangazi University, Eskişehir, Turkey. ${ }^{3}$ Department of Pharmacology, Faculty of Medicine, Eskişehir Osmangazi \\ University, Eskişehir, Turkey. ${ }^{4}$ Private Practice, Eskişehir, Turkey.
}

\begin{abstract}
Objective: To date, no study has investigated whether autogenous and reactive obsessivecompulsive disorder (OCD) types are different entities in terms of oxidative stress and inflammatory processes. The aim of this study is to compare them in terms of these features.

Methods: The study was conducted in subjects with reactive OCD $(n=19)$, autogenous OCD $(n=14)$, and a control group $(n=17)$. All participants were non-smokers. Sociodemographic data were collected and the Yale-Brown Obsessive-Compulsive Scale (Y-BOCS), Beck Anxiety Inventory (BAI), Beck Depression Inventory (BDI), Obsessive Beliefs Questionnaire (OBQ), and Overvalued Ideas Scale (OVIS) were administered. High-sensitivity C-reactive protein (hs-CRP), interleukin-6 (IL-6), interleukin-10 (IL-10), paraoxonase (PON1), total oxidant status (TOS), and total antioxidant status (TAS) were measured.

Results: There were no significant differences in TAS, TOS, or oxidative stress index (OSI) between the OCD and control groups. PON1 and hs-CRP levels were higher in the OCD group, whereas IL-6 and IL-10 levels were lower. Comparison across the three groups revealed no differences in TAS, TOS, OSI, or PON1 levels; however, hs-CRP was significantly higher while IL-6 and IL-10 were significantly lower in the reactive group compared to controls.

Conclusion: Our results show that, although inflammatory processes may play a role in OCD, the autogenous and reactive subtypes do not differ from each other in these respects. The classification of OCD into autogenous and reactive subtypes should be reevaluated.
\end{abstract}

Keywords: Obsessive-compulsive disorder; oxidative stress; inflammatory process; autogenous; reactive

\section{Introduction}

Obsessive-compulsive disorder (OCD) is a common psychiatric disorder characterized by obsessions and compulsions that create serious difficulties for patients and their families. Its prevalence in the general population is estimated to be 2 to $3 \%{ }^{1}$ Although the etiology of OCD is still unclear, various studies have suggested that it is multifactorial. $^{2}$ OCD is a heterogeneous disorder, which can be classified as autogenous or reactive OCD according to the types of obsessions. Autogenous obsessions are those that mostly come to the mind without a detectable stimulus, are alien to the self, and include themes of aggression, sex, and blasphemy. On the other hand, reactive obsessions are evoked by

Correspondence: Melis Danışman Sonkurt, Ağrı Devlet Hastanesi Psikiyatri Polikliniği Fırat Mahallesi, Merkez, Ağrı, Turkey, 04100.

E-mail: melisdanisman13@gmail.com

Submitted Jan 10 2021, accepted Apr 17 2021, Epub Jun 232021. identifiable external stimuli and include more realistic and rational themes, such as contamination, symmetry, order, and somatic obsessions. ${ }^{3}$ It has been suggested that autogenous and reactive obsessions arise from different psychological mechanisms, and the autogenic subtype has been found to respond poorly to treatment. ${ }^{4}$ To date, no study had investigated whether the autogenous and reactive subtypes are different entities in terms of oxidative stress and inflammatory processes.

Oxidative stress can be defined as an imbalance between oxidants and antioxidants which results in macromolecular cell damage. The brain is more susceptible to oxidation than other tissues due to its higher content of unsaturated fatty acids, oxygen per unit weight, lipid peroxidation, and relatively weaker antioxidant

How to cite this article: Danışman Sonkurt M, Altınöz AE, Kosger F, Yiğitaslan S, Güleç G, Eşsizoğlu A. Are there differences in oxidative stress and inflammatory processes between the autogenous and reactive subtypes of obsessive-compulsive disorder? A controlled cross-sectional study. Braz J Psychiatry. 2022;44: 171-177. http://dx.doi.org/10.1590/1516-4446-2021-1740 
defense system. ${ }^{5}$ Studies have shown that oxidative stress and free radicals affect the brain tissues of OCD patients. ${ }^{6,7}$ It has been reported that imbalances in antioxidant vitamin levels, ${ }^{7,8}$ increased free radicals, ${ }^{6}$ and metabolites of lipid peroxidation induced by increased free radicals ${ }^{9}$ may play a potential role in the etiopathogenesis of OCD. On the other hand, some studies have found increased superoxide dismutase (SOD), an antioxidant enzyme, and decreased malondialdehyde (MDA), an indicator of oxidative damage, in OCD patients, ${ }^{10}$ or a disruption in oxidative balance in favor of antioxidants in OCD patients. ${ }^{11}$

There is increasing evidence that immunological dysfunctions exist in a significant subset of OCD patients. ${ }^{12}$ The finding that pediatric autoimmune neuropsychiatric diseases (PANDAS), especially that associated with beta-hemolytic streptococcal infection, may play a role in the etiopathogenesis of OCD has resulted in an increase in studies investigating the relationship between specific OCD subtypes and inflammatory processes. ${ }^{13} \mathrm{~A}$ meta-analysis examining the possible role of cytokines in OCD etiology showed reduced levels of IL- $1 \beta$ in OCD patients as compared to healthy controls, increased levels of IL-6 in drug-free OCD patients as compared to treated patients, and increased levels of tumor necrosis factor $\alpha$ (TNF- $\alpha$ ) in OCD with comorbid depression. ${ }^{14}$ However, the results of studies investigating the role of inflammatory processes in OCD are quite inconsistent.

In this respect, the aim of this study is to compare autogenic and reactive OCD patients in terms of oxidative stress and inflammatory processes. We hypothesize that oxidative stress and inflammatory processes play a more important role in autogenic OCD, which is known to respond poorly to treatment, than in reactive OCD.

\section{Methods}

Our study included patients who were diagnosed with OCD according to the Structured Clinical Interview (SCID) for DSM-5 diagnostic criteria and admitted to the Outpatient Psychiatry Clinic of Eskişehir Osmangazi University, Medical Faculty Hospital, between April 15, 2016, and December 15, 2016. Healthy volunteers matched for age and sex composed the control group. Patients were interviewed by an experienced psychiatrist in a clinical interview and divided into two groups, autogenous or reactive $O C D$, in accordance with the criteria put forth in the studies of Lee \& Kwon. ${ }^{4}$ Therefore, the study was conducted on two OCD groups and one control group. A total of 33 patients with OCD (19 reactive and 14 autogenous) and 17 healthy age and sex-matched controls were included in the study.

Exclusion criteria included chronic noncommunicable diseases (such as diabetes, hypertension, hyperlipidemia, kidney disease, coronary heart disease, stroke, or connective tissue disease), current or past alcohol and substance disorder, presence of any central nervous system diseases, mental retardation, previous diagnosis of bipolar disorder or psychosis, chronic or acute infections, history of antibiotic or anti-inflammatory drug use within the 6 months prior to the study, use of any drug or nutritional supplement (including vitamins and fish oil) in the past 1 month, and current smoking or quitting in less than 6 months. The healthy control group was recruited by the snowball method. ${ }^{15}$ With this method, Eskişehir Osmangazi University staff was informed about the study, and the participants informed their colleagues about the participation to the study. A psychiatric interview was applied to the healthy control group, as well as the same exclusion criteria applied to the OCD groups. Those who had a previous/ongoing psychiatric history were excluded from the study.

The scales and questionnaires administered to the participants are described below.

\section{Sociodemographic data form}

In addition to the general sociodemographic data of the participants, this form, prepared by the researchers, included information such as smoking, use of herbal products, age at diagnosis, type of treatment, and presence of physical illness, in order to determine whether some conditions that may be related to oxidative stress were present.

\section{Yale-Brown Obsessive-Compulsive Scale (Y-BOCS)}

The Y-BOCS was developed by Goldman, Price, and Rassmussen and adapted to Turkish by Karamustafaoglu et al. $^{16}$ The scale was designed to evaluate symptom subgroups and severity in patients with OCD. It consists of 19 items and is scored by the interviewer. The first 10 items are used to calculate the total score.

\section{Beck Depression Inventory (BDI)}

The BDI was developed in 1961 by Beck et al. It is a 21-item self-assessment scale that measures physical, emotional, cognitive and motivational symptoms of depression. A validity and reliability study was conducted by Hisli in our country. ${ }^{17}$

\section{Beck Anxiety Inventory (BAI)}

The BAI was developed in 1988 by Beck et al. It is used to determine the frequency and severity of anxiety symptoms experienced by individuals and is a self-report instrument. Its validity and reliability in Turkey were confirmed by Ulusoy et al. ${ }^{18}$

\section{Obsessive Beliefs Questionnaire (OBQ)}

The OBQ is a 7-point, Likert-type self-assessment scale, anchored from strongly disagree to completely agree, which evaluates beliefs associated with obsessive-compulsive symptoms. In this study, we used the 44-item scale developed by the Obsessive-Compulsive Cognitions Working Group. The validity and reliability of this scale were confirmed by Boysan et al. in our country. ${ }^{19}$ The scale contains three subscales: responsibility and 
danger, perfectionism and certainty, and importance of control of thoughts.

\section{Overvalued Ideas Scale (OVIS)}

The OVIS was developed by Neziroğlu et al. with the aim of providing a quantitative assessment of the level of insight in OCD. ${ }^{20}$ After the development of the scale, the authors evaluated Overvalued Ideas as a reliable indicator of poor insight in OCD and patients with an OVIS score of $\geqslant 6$ were considered to have "OCD with poor insight." This 11-item scale, scored between 1 and 10 , is scored by the interviewer, taking specific beliefs into consideration. The OVIS score is calculated using the average of the scores obtained from each item.

\section{Analysis of biomarkers}

Blood samples were collected from all participants in the outpatient psychiatry clinic between 9:30 and 10:30 am, after at least 8 hours of fasting. Samples were then sent to the pharmacology department for measurement of high-sensitivity C-reactive protein (hs-CRP), interleukin-6 (IL-6), interleukin-10 (IL-10), paraoxonase (PON1), total antioxidant status (TAS), and total oxidant status (TOS). The blood samples were rested at room temperature for 15 minutes and centrifuged at 3,000 $\times \mathrm{g}$. The samples were then stored at $-80^{\circ} \mathrm{C}$ for up to 2 months until analysis. Serum levels of hs-CRP, IL-6, and IL-10 (biomarkers of inflammation) were analyzed using commercially available enzyme-linked immunosorbent assay (ELISA) kits following the manufacturer's instructions. TAS, TOS, and paraoxonase levels (biomarkers of oxidative stress) were also analyzed by ELISA. The oxidative stress index (OSI) was then calculated according to the formula OSI = TOS/TAS.

\section{Statistical analysis}

Data were calculated as mean \pm standard deviation. Categorical data were given as percentage (\%). The Shapiro-Wilk test was used to investigate the normality of distribution. For non-normally distributed data, the Mann-Whitney $U$ test was used for comparisons between two groups and the Kruskal-Wallis $H$ test for comparisons across three or more groups. Pearson chi-square analysis was used for analysis of cross tables. Post-hoc Bonferroni correction was performed. SPSS version 21.0 was used for all analyses. Significance was set at $p<0.05$.

\section{Ethics statement}

The study was approved by the local ethics committee and supported by the Rectorate of Eskişehir Osmangazi University within the scope of its scientific research project (2016-1237). All participants were informed about the study and provided written consent.

\section{Results}

A total of 33 patients with OCD (19 reactive and 14 autogenous) and 17 healthy, age- and sex-matched controls were included in the study. Comparison of BDI and BAI scores in the control and OCD groups revealed significantly higher scores in the OCD patients $(z=24.273$ and $p<0.001, z=23.492$ and $p<0.001$, respectively) (Table 1).

Comparison of oxidative stress markers in the control and OCD groups (i.e., with both OCD subgroups pooled) revealed no difference in TAS, TOS, or OSI between the two groups $(\mathrm{H}=-0.180$ and $\mathrm{p}=0.857, \mathrm{H}=-0.411$ and $p=0.681, H=-0.522$ and $p=0.601$, respectively), whereas PON1 and hs-CRP were significantly higher, and IL- 6 and IL-10 levels were significantly lower in the OCD group $(\mathrm{H}=-2.356$ and $\mathrm{p}=0.018, \mathrm{H}=-2.904$ and $\mathrm{p}=0.004, \mathrm{H}=3.057$ and $\mathrm{p}=0.002, \mathrm{H}=2.727$ and $\mathrm{p}=$ 0.006) (Table 2).

Comparison of the control, autogenous OCD, and reactive OCD groups in terms of oxidative stress and inflammatory markers revealed no differences in TAS, TOS, OSI, or PON1 across groups $(H=1.217$ and $p=$ $0.544, H=1.064$ and $p=0.588, H=0.564$ and $p=0.754$, $H=5.736$ and $p=0.057$, respectively), whereas hs-CRP, IL-6, and IL-10 levels were significantly different $(\mathrm{H}=$ 9.197 and $p=0.010, H=9.552$ and $p=0.008, H=7.541$ and $p=0.023$ ). Post-hoc analysis showed that higher levels of hs-CRP and lower levels of IL- 6 and IL- 10 were more significant in the reactive OCD group compared to the control group (Table 3).

There was no significant difference in age at onset, duration of disease, duration of treatment, OVIS score,

Table 1 Distribution of groups by sex and age and comparison in BDI and BAI scores

\begin{tabular}{|c|c|c|c|c|c|}
\hline & \multirow[b]{2}{*}{ Reactive $(n=19)$} & \multirow[b]{2}{*}{ Autogenous $(n=14)$} & \multirow{2}{*}{$\begin{array}{c}\text { Control } \\
(n=17)\end{array}$} & \multicolumn{2}{|c|}{ Statistics } \\
\hline & & & & $\chi^{2} / \mathrm{H} / \mathrm{Z}$ & $p$-value \\
\hline \multicolumn{6}{|l|}{ Sex } \\
\hline Male & $5(21.7)$ & $2(8.7)$ & $7(41.1)$ & & \\
\hline Female & $14(35.0)$ & $12(30.0)$ & $10(60.9)$ & 2.797 & 0.247 \\
\hline Age & $33.95 \pm 10.19$ & $33.50 \pm 12.23$ & $32.12 \pm 3.28$ & 0.609 & 0.738 \\
\hline BDI & $19.72 \pm 13.78$ & $24.54 \pm 15.90$ & $2.82 \pm 1.84$ & 24.273 & $<0.001$ \\
\hline BAI & $20.33 \pm 15.93$ & $24.83 \pm 18.50$ & $2.88 \pm 2.42$ & 23.492 & $<0.001$ \\
\hline
\end{tabular}

Data presented as $\mathrm{n}(\%)$ or mean \pm standard deviation.

$\mathrm{BAI}=$ Beck Anxiety Inventory; BDI = Beck Depression Inventory. 
Table 2 Comparison of oxidative stress and inflammatory markers in the control and obsessive-compulsive disorder (pooled) groups

\begin{tabular}{|c|c|c|c|c|}
\hline $\begin{array}{l}\text { Oxidative stress and } \\
\text { inflammatory markers }\end{array}$ & $\begin{array}{l}\text { Reactive }+ \text { autogenous } \\
\qquad(n=33)\end{array}$ & Control $(n=17)$ & $\mathrm{H}$ & $\mathrm{p}$-value \\
\hline Total antioxidant status & $\begin{array}{l}1.01 \pm 0.31 \\
{[0.76-1.20]}\end{array}$ & $\begin{array}{l}1.05 \pm 0.28 \\
{[0.93-1.20]}\end{array}$ & -0.180 & 0.857 \\
\hline Total oxidant status & $\begin{array}{c}29.06 \pm 19.34 \\
{[7.31-42.48]}\end{array}$ & $\begin{array}{l}27.25 \pm 15.51 \\
{[12.55-39.91]}\end{array}$ & -0.411 & 0.681 \\
\hline Oxidative stress index & $\begin{array}{l}30.06 \pm 17.69 \\
{[17.64-40.67]}\end{array}$ & $\begin{array}{l}27.63 \pm 13.97 \\
{[19.09-34.67]}\end{array}$ & -0.522 & 0.601 \\
\hline Paraoxonase & $\begin{array}{l}371.45 \pm 297.03 \\
{[62.50-700.00]}\end{array}$ & $\begin{array}{l}132.59 \pm 223.14 \\
{[24.50-110.00]}\end{array}$ & -2.356 & 0.018 \\
\hline Interleukin-6 & $\begin{array}{l}23.91 \pm 26.13 \\
{[12.00-22.00]}\end{array}$ & $\begin{array}{l}39.70 \pm 31.95 \\
{[20.00-57.00]}\end{array}$ & 3.057 & 0.002 \\
\hline High-sensitivity C-reactive protein & $\begin{array}{l}5,115.15 \pm 3,436.17 \\
{[2,250.00-8,500.00]}\end{array}$ & $\begin{array}{c}2,514.71 \pm 3,231.76 \\
{[350.00-3,375.00]}\end{array}$ & -2.904 & 0.004 \\
\hline Interleukin-10 & $\begin{array}{l}485.87 \pm 268.72 \\
{[280.00-675.00]}\end{array}$ & $\begin{array}{l}673.82 \pm 163.60 \\
{[555.00-787.50]}\end{array}$ & 2.727 & 0.006 \\
\hline
\end{tabular}

Data presented as mean \pm standard deviation [interquartile range].

Bold type denotes statistical significance.

Table 3 Comparison of oxidative stress and inflammatory markers in the control, autogenous OCD, and reactive OCD groups

\begin{tabular}{|c|c|c|c|c|c|c|}
\hline Marker & $\begin{array}{l}\text { Reactive } \\
(n=19)\end{array}$ & $\begin{array}{l}\text { Autogenous } \\
\quad(n=14)\end{array}$ & $\begin{array}{l}\text { Control } \\
(n=17)\end{array}$ & $\mathrm{H}$ & $p$-value & $\begin{array}{l}\text { Pairwise } \\
\text { comparison }\end{array}$ \\
\hline Total antioxidant status & $\begin{array}{l}1.06 \pm 0.29 \\
{[0.90-1.20]}\end{array}$ & $\begin{array}{l}0.94 \pm 0.34 \\
{[0.49-1.20]}\end{array}$ & $\begin{array}{l}1.05 \pm 0.28 \\
{[0.93-1.20]}\end{array}$ & 1.217 & 0.544 & - \\
\hline Total oxidant status & $\begin{array}{l}32.27 \pm 15.43 \\
{[30.05-41.55]}\end{array}$ & $\begin{array}{r}26.85 \pm 21.31 \\
{[4.00-49.77]}\end{array}$ & $\begin{array}{l}27.72 \pm 14.66 \\
{[12.55-39.90]}\end{array}$ & 1.064 & 0.588 & - \\
\hline Oxidative stress index & $\begin{array}{l}31.35 \pm 15.37 \\
{[25.23-37.03]}\end{array}$ & $\begin{array}{c}28.30 \pm 20.91 \\
{[7.09-42.40]}\end{array}$ & $\begin{array}{l}27.63 \pm 13.97 \\
{[19.09-34.67]}\end{array}$ & 0.564 & 0.754 & - \\
\hline Paraoxonase & $\begin{array}{l}377.05 \pm 309.37 \\
{[90.00-700.00]}\end{array}$ & $\begin{array}{l}366.86 \pm 290.77 \\
{[21.50-685.00]}\end{array}$ & $\begin{array}{l}132.59 \pm 223.14 \\
{[24.50-110.00]}\end{array}$ & 5.736 & 0.057 & - \\
\hline Interleukin-6 & $\begin{array}{c}18.10 \pm 5.83 \\
{[13.00-21.00]}\end{array}$ & $\begin{array}{l}31.78 \pm 38.95 \\
{[8.25-40.00]}\end{array}$ & $\begin{array}{l}39.71 \pm 31.96 \\
{[20.00-57.00]}\end{array}$ & 9.552 & 0.008 & $\begin{array}{c}\text { Control }>\text { reactive } \\
p=0.10\end{array}$ \\
\hline $\begin{array}{l}\text { High-sensitivity } \\
\text { C-reactive protein }\end{array}$ & $\begin{array}{l}5,665.79 \pm 3,269.81 \\
{[3,250.00-8,500.00]}\end{array}$ & $\begin{array}{l}4,367.86 \pm 3,635.33 \\
{[1,362.50-8,125.00]}\end{array}$ & $\begin{array}{c}2,514.71 \pm 3,231.76 \\
{[350.00-3,375.00]}\end{array}$ & 9.197 & 0.010 & $\begin{array}{c}\text { Reactive }>\text { control } \\
p=0.08\end{array}$ \\
\hline IL-10 & $\begin{array}{l}472.58 \pm 284.40 \\
{[280.00-550.00]}\end{array}$ & $\begin{array}{l}503.93 \pm 255.27 \\
{[275.00-812.50]}\end{array}$ & $\begin{array}{l}673.82 \pm 163.60 \\
{[555.00-787.50]}\end{array}$ & 7.541 & 0.023 & $\begin{array}{c}\text { Control > reactive } \\
p=0.29\end{array}$ \\
\hline
\end{tabular}

Data presented as mean \pm standard deviation [interquartile range].

hs-CRP = high sensitive C-Reactive Protein; IL-6 = interleukin-6; IL-10 = interleukin-10; PON1 = paraoxonase; SD = standard deviation;

TAS $=$ total antioxidant status; TOS $=$ total oxidant status.

Bold type denotes statistical significance.

OBQ score, or Y-BOCS score between the two OCD subgroups ( $p>0.05$ ). The psychometric scores of both groups are presented in Table 4.

\section{Discussion}

In our study, there was no difference in markers of oxidative stress or inflammation between the autogenous and reactive OCD subtypes. However, hs-CRP levels were significantly higher and IL- 6 and IL-10 levels were significantly lower in the reactive OCD group compared to the control group. In this context, the difference between the OCD group and healthy controls seems to result from the reactive OCD subgroup. This does not support our hypothesis suggesting that the autogenous subtype, which has a lower treatment response rate, is associated with greater oxidative stress and inflammation compared to the reactive subtype. Various studies have suggested an association between stress and inflammation, revealing that acute stress primarily stimulates inflammatory 
Table 4 Psychometric scores of obsessive-compulsive disorder groups and comparison of these scores between groups

\begin{tabular}{|c|c|c|c|c|}
\hline & Reactive $(n=19)$ & Autogenous $(n=14)$ & Z & $p$-value \\
\hline Age at onset & $\begin{array}{c}21.00 \pm 7.27 \\
{[14.00-27.25]}\end{array}$ & $\begin{array}{c}17.00 \pm 8.84 \\
{[13.25-28.75]}\end{array}$ & -1.545 & 0.125 \\
\hline Duration of disease & $\begin{array}{l}11.78 \pm 11.02 \\
{[3.00-22.00]}\end{array}$ & $\begin{array}{l}15.61 \pm 12.14 \\
{[5.25-12.00]}\end{array}$ & 1.404 & 0.170 \\
\hline Duration of treatment & $\begin{array}{l}3.43 \pm 4.99 \\
{[1.00-4.50]}\end{array}$ & $\begin{array}{l}8.91 \pm 9.33 \\
{[1.25-7.50]}\end{array}$ & 1.912 & 0.066 \\
\hline OVIS & $\begin{array}{l}3.34 \pm 1.21 \\
{[2.47-4.80]}\end{array}$ & $\begin{array}{l}3.70 \pm 1.12 \\
{[3.25-4.71]}\end{array}$ & 0.628 & 0.536 \\
\hline $\mathrm{OBQ}$, total score & $\begin{array}{c}189.00 \pm 54.45 \\
{[173.50-240.75]}\end{array}$ & $\begin{array}{c}194.15 \pm 49.63 \\
{[165.25-203.00]}\end{array}$ & 0.180 & 0.859 \\
\hline OBQ, responsibility/threat estimation & $\begin{array}{l}73.62 \pm 23.72 \\
{[58.75-97.75]}\end{array}$ & $\begin{array}{l}78.73 \pm 17.89 \\
{[56.75-82.50]}\end{array}$ & 0.617 & 0.544 \\
\hline OBQ, perfectionism/certainty & $\begin{array}{c}81.62 \pm 19.83 \\
{[80.25-101.00]}\end{array}$ & $\begin{array}{l}71.45 \pm 19.07 \\
{[53.75-82.25]}\end{array}$ & -1.431 & 0.162 \\
\hline OBQ, importance/control of thoughts & $\begin{array}{l}41.12 \pm 16.69 \\
{[30.50-59.00]}\end{array}$ & $\begin{array}{c}51.27 \pm 15.30 \\
{[42.75-62.00]}\end{array}$ & 1.624 & 0.111 \\
\hline Y-BOCS, total score & $\begin{array}{c}19.06 \pm 9.85 \\
{[18.25-30.00]}\end{array}$ & $\begin{array}{c}21.75 \pm 8.12 \\
{[13.00-29.25]}\end{array}$ & 0.466 & 0.647 \\
\hline Y-BOCS, obsession & $\begin{array}{c}9.59 \pm 4.62 \\
{[9.00-15.00]}\end{array}$ & $\begin{array}{l}12.17 \pm 4.11 \\
{[8.50-15.00]}\end{array}$ & 1.425 & 0.166 \\
\hline Y-BOCS, compulsion & $\begin{array}{c}9.47 \pm 5.69 \\
{[7.75-15.00]}\end{array}$ & $\begin{array}{c}9.58 \pm 5.57 \\
{[5.75-14.25]}\end{array}$ & -0.067 & 0.948 \\
\hline
\end{tabular}

Data presented as mean \pm standard deviation [interquartile range].

$\mathrm{OBQ}=$ Obsessive Beliefs Questionnaire; OVIS = Overvalued Ideas Scale; SD = standard deviation; Y-BOCS = Yale Brown ObsessiveCompulsive Scale.

processes, while chronic stress is often associated with dysregulation or inhibition of such processes. ${ }^{21}$ Therefore, lower IL-6 and 10 may result from this inhibition, which would be consistent with the chronicity of OCD. Besides TNF- $\alpha$ and IL-1 $\beta$, IL- 6 is one of the most investigated proinflammatory cytokines in OCD. Although there are conflicting data, many studies have reported low levels of IL-6 in OCD. ${ }^{22-25} \mathrm{~A}$ recent review revealed that patients with $O C D$ receiving disease-specific drugs were characterized by significantly lower plasma levels of IL-6, suggesting that this finding be compared with those not undergoing treatment. ${ }^{24}$ Although IL-6 is classified as a proinflammatory cytokine, in vitro studies have shown that it plays a role in a local and systemic feedback mechanism by blocking the effects of TNF- $\alpha .{ }^{26}$ The versatility of its effects on the inflammation process and heterogeneity of the existing literature in many variables, such as the age of the patients, duration and severity of the disease, and medication use, may explain the differences in findings regarding IL-6.

We compared the TAS, TOS, and OSI scores (indicators of general oxidative status) and levels of PON1 (an antioxidant enzyme) and found no significant difference between the OCD and control groups in terms of the TAS and TOS scores, whereas the mean PON1 level was significantly higher in the OCD group compared to the control group $(p<0.05)$. Although there was no significant difference, TAS levels were higher in the reactive and autogenous OCD groups compared to the control group. These findings may be explained by increased defensive mechanisms and rebound increase in antioxidant levels against a chronic disease, as suggested by Selek et al., who obtained similar results in their studies, or by the fact that OCD may be one of several syndromes associated with high antioxidant levels, such as polycystic ovary syndrome. ${ }^{11}$

To our knowledge, this is the first study in the literature to investigate PON1 levels in adults with OCD. In 2013, Kandemir et al. investigated oxidative stress in children and adolescents with OCD, and found that PON1 levels were significantly low. ${ }^{27} \mathrm{~A}$ recent review concluded that low PON1 levels may play a key role in mood disorders, generalized anxiety disorder and schizophrenia co-occurring with oxidative stress processes, and that therapies which aim to increase PON1 activity are likely to be novel drug targets for the treatment of these diseases. ${ }^{28}$ In our study, the lower PON1 scores in healthy controls can be attributed to the fact that the OCD patients included in the study were under treatment. Human and animal studies investigating the effects of antidepressants on oxidative stress suggest that these agents may increase antioxidant activity. ${ }^{29-31}$

Although IL-6 and IL-10 were found to be significantly lower and hs-CRP was higher in the OCD group compared 
to the control group, this difference was not significant between the two OCD subtypes.

C-reactive protein (CRP), an acute-phase protein, has been the focus of extensive epidemiological investigations after association of its high plasma levels ( $>3 \mathrm{mg} / \mathrm{L}$ ) with cardiovascular risk. ${ }^{32}$ Studies have shown that it is increased in major depression and correlates with symptom severity ${ }^{33}$ and is significantly increased in generalized anxiety disorder, ${ }^{34}$ thus suggesting that it can be used as a biomarker to differentiate between bipolar depression and major depression. ${ }^{35}$ To the best of our knowledge, there have been no studies investigating hs-CRP levels in OCD patients to date, and the significant increase in our study is consistent with findings in other psychiatric disorders. This may also indicate that inflammatory processes are involved in OCD, as in other psychiatric disorders. It is well known that serum IL-6 induces CRP secretion in the liver. ${ }^{36}$ In our study, while IL-6 levels were low in the OCD group, hs-CRP was found to be high. These data can be explained by the mechanisms whereby the CRP gene expression is regulated by IL- 6 independently. ${ }^{37}$ For example, in a study with more than 3,000 participants, individuals were divided into CRP-dominant, IL-6-dominant, and co-dominant groups, and an increased risk of stroke was found in the CRP-dominant group. ${ }^{37}$ In the future, studies in which levels of these two parameters are measured separately (as well as their ratios to each other) in psychiatric disorders may contribute to the literature.

The fact that there were no differences in OVIS, OBQ, and Y-BOCS scores between the reactive and autogenous OCD groups is inconsistent with previous studies revealing that both symptom severity and relevant scale scores were higher in the autogenous subtype than the reactive subtype. ${ }^{38}$ This indicates that the classification of OCD into autogenous and reactive subtypes needs to be reevaluated.

Our study had some limitations: the small sample size, cross-sectional design, and presence of possible additional diagnoses based on BDI and BAl scores, which was a confounding factor. Research has indicated that medication may have an effect on anti-inflammatory and oxidative biomarkers. ${ }^{39,40}$ In our sample, every patient was on antidepressants; however, there were no statistical analysis regarding the known effects of medication. Furthermore, body mass index may act as a confounding factor on oxidative stress markers, and our data did not include this parameter. Conversely, the exclusion of all controllable agents known to affect both inflammatory and oxidative stress markers was one of the strengths of our study.

In conclusion, the results of our study indicate that inflammatory processes may play a role in OCD. However, autogenous and reactive OCD do not differ from each other in these aspects.

\section{Acknowledgements}

This research was funded by a Eskişehir Osmangazi University scientific research projects grant (2016/1237). We thank them for their support.

\section{Disclosure}

The authors report no conflicts of interest.

\section{References}

1 Ruscio AM, Stein DJ, Chiu WT, Kessler RC. The epidemiology of obsessive-compulsive disorder in the National Comorbidity Survey Replication. Mol Psychiatry. 2010;15:53-63.

2 Goodman WK, Grice DE, Lapidus KA, Coffey BJ. Obsessivecompulsive disorder. Psychiatr Clin North Am. 2014;37:257-67.

3 Besiroglu L, Agargun MY, Ozbebit O, Aydin A. A discrimination based on autogenous versus reactive obsessions in obsessive-compulsive disorder and related clinical manifestations. CNS Spectr. 2006;11: 179-86.

4 Lee HJ, Kwon SM. Two different types of obsession: autogenous obsessions and reactive obsessions. Behav Res Ther. 2003;41: 11-29.

5 Halliwell B. Oxidative stress and neurodegeneration: where are we now? J Neurochem. 2006;97:1634-58.

6 Kuloglu M, Atmaca M, Tezcan E, Gecici O, Tunckol H, Ustundag B. Antioxidant enzyme activities and malondialdehyde levels in patients with obsessive-compulsive disorder. Neuropsychobiology. 2002;46: 27-32.

7 Ersan S, Bakir S, Erdal Ersan E, Dogan O. Examination of free radical metabolism and antioxidant defence system elements in patients with obsessive-compulsive disorder. Prog Neuropsychopharmacol Biol Psychiatry. 2006;30:1039-42.

$8 \mathrm{MH}$ S, Ullah A, Azad M, MA I, Qusar M, Hasnat A. Serum antioxidant vitamins and malondialdehyde levels in patients with obsessivecompulsive disorder. Ger J Psychiatry. 2012;15:10-4.

9 Chakraborty S, Singh OP, Dasgupta A, Mandal N, Das HN. Correlation between lipid peroxidation-induced TBARS level and disease severity in obsessive-compulsive disorder. Prog Neuropsychopharmacol Biol Psychiatry. 2009;33:363-6.

10 Behl A, Swami G, Sircar SS, Bhatia MS, Banerjee BD. Relationship of possible stress-related biochemical markers to oxidative/antioxidative status in obsessive-compulsive disorder. Neuropsychobiology. 2010;61:210-4.

11 Selek S, Herken H, Bulut M, Ceylan MF, Celik H, Savas HA, et al. Oxidative imbalance in obsessive compulsive disorder patients: a total evaluation of oxidant-antioxidant status. Prog Neuropsychopharmacol Biol Psychiatry. 2008;32:487-91.

12 Gerentes M, Pelissolo A, Rajagopal K, Tamouza R, Hamdani N. Obsessive-compulsive disorder: autoimmunity and neuroinflammation. Curr Psychiatry Rep. 2019;21:78.

13 Swedo SE, Leonard HL, Garvey M, Mittleman B, Allen AJ, Perlmutter $\mathrm{S}$, et al. Pediatric autoimmune neuropsychiatric disorders associated with streptococcal infections: clinical description of the first 50 cases. Am J Psychiatry. 1998;155:264-71.

14 Gray SM, Bloch MH. Systematic review of proinflammatory cytokines in obsessive-compulsive disorder. Curr Psychiatry Rep. 2012;14: 220-8.

15 Goodman LA. Snowball sampling. Ann Math Statist. 1961;32:148-70.

16 Karamustafalıoğlu O, Üçışık AM, Ulusoy M, Erkmen H. Yale-Brown Obsesyon-Kompülsiyon Derecelendirme Ölçeğinin Geçerlilik ve Güvenilirlik Çalıșması. In: 29. Ulusal Psikiyatri Kongresi Program ve Bildiri Ozetleri Kitabı. Bursa: Savaş Ofset; 1993.

17 Hisli N. Beck Depresyon envanterinin geçerliliğiüzerine bir çalışma. Psikoloji Dergisi. 1988;22:118-26.

18 Ulusoy M. Beck Anksiyete Envanteri-geçerlik ve güvenirlik çalışması. İstanbul: Bakırköy Ruh ve Sinir Hastalıkları Hastanesi; 1993.

19 Boysan M, Besiroglu L, Cetinkaya N, Atli A, Aydin A. The validity and reliability of the Turkish version of the obsessive beliefs questionnaire-44 (OBQ-44). Noro Psikiyatr Ars. 2010;47:216-22.

20 Neziroglu F, McKay D, Yaryura-Tobias JA, Stevens KP, Todaro J. The overvalued ideas scale: development, reliability and validity in obsessive-compulsive disorder. Behav Res Ther. 1999;37:881-902.

21 Dhabhar FS. Effects of stress on immune function: the good, the bad, and the beautiful. Immunol Res. 2014;58:193-210.

22 Denys D, Fluitman S, Kavelaars A, Heijnen C, Westenberg $H$. Decreased TNF- $\alpha$ and NK activity in obsessive-compulsive disorder. Psychoneuroendocrinology. 2004;29:945-52. 
23 Fluitman S, Denys D, Vulink N, Schutters S, Heijnen C, Westenberg $H$. Lipopolysaccharide-induced cytokine production in obsessivecompulsive disorder and generalized social anxiety disorder. Psychiatry Res. 2010;178:313-6.

24 Marazziti D, Mucci F, Lombardi A, Falaschi V, Dell'Osso L. The cytokine profile of OCD: pathophysiological insights. Int J Interferon Cytokine Mediat Res. 2015;7:35-42.

25 Erbay LG, Kavuran NA, Taşkapan Ç, Lara Utku I, Yoloğlu S, Temelli HG, et al. Serum IL-1, IL-2, IL-4, IL-6, IL-10, TNF- $\alpha$, and IFN- $\gamma$ levels in drug-free, comorbidity-free obsessive-compulsive disorder patients. Anadolu Psikiyatri Derg. 2018;19:157-62.

26 Xing Z, Gauldie J, Cox G, Baumann H, Jordana M, Lei XF, et al. IL-6 is an antiinflammatory cytokine required for controlling local or systemic acute inflammatory responses. J Clin Invest. 1998;101:311-20.

27 Kandemir H, Abuhandan M, Aksoy N, Savik E, Kaya C. Oxidative imbalance in child and adolescent patients with obsessive compulsive disorder. J Psychiatr Res. 2013;47:1831-4.

28 Moreira EG, Boll KM, Correia DG, Soares JF, Rigobello C, Maes M. Why should psychiatrists and neuroscientists worry about paraoxonase 1? Curr Neuropharmacol. 2019;17:1004-20.

29 Jiménez-Fernández S, Gurpegui M, Díaz-Atienza F, Pérez-Costillas L, Gerstenberg M, Correll CU. Oxidative stress and antioxidant parameters in patients with major depressive disorder compared to healthy controls before and after antidepressant treatment: results from a meta-analysis. J Clin Psychiatry. 2015;76:1658-67.

30 Rebai R, Jasmin L, Boudah A. The antidepressant effect of melatonin and fluoxetine in diabetic rats is associated with a reduction of the oxidative stress in the prefrontal and hippocampal cortices. Brain Res Bull. 2017;134:142-50.

31 Black CN, Bot M, Scheffer PG, Penninx BW. Oxidative stress in major depressive and anxiety disorders, and the association with antidepressant use; results from a large adult cohort. Psychol Med. 2017;47:936-48.
32 Emerging Risk Factors Collaboration; Kaptoge S, Di Angelantonio E, Lowe G, Pepys MB, Thompson SG, et al. C-reactive protein concentration and risk of coronary heart disease, stroke, and mortality: an individual participant meta-analysis. Lancet. 2010;375: 132-40.

33 Köhler-Forsberg O, Buttenschøn HN, Tansey KE, Maier W, Hauser J, Dernovsek MZ, et al. Association between C-reactive protein (CRP) with depression symptom severity and specific depressive symptoms in major depression. Brain Behav Immun. 2017;62:344-50.

34 Copeland WE, Shanahan L, Worthman C, Angold A, Costello EJ. Generalized anxiety and C-reactive protein levels: a prospective, longitudinal analysis. Psychol Med. 2012;42:2641-50.

35 Chang HH, Wang TY, Lee IH, Lee SY, Chen KC, Huang SY, et al. C-reactive protein: a differential biomarker for major depressive disorder and bipolar II disorder. World J Biol Psychiatry. 2017;18: 63-70.

36 Shine B, de Beer FC, Pepys MB. Solid phase radioimmunoassays for human C-reactive protein. Clin Chim Acta. 1981;117:13-23.

37 Luna JM, Moon YP, Liu KM, Spitalnik S, Paik MC, Cheung K, et al. High-sensitivity C-reactive protein and interleukin-6-dominant inflammation and ischemic stroke risk: the Northern Manhattan Study. Stroke. 2014;45:979-87.

38 Batmaz S, Yildiz M, Songur E. Psychopharmacological treatment differences in autogenous and reactive obsessions: a retrospective chart review. Nord J Psychiatry. 2016;70:31-7.

39 Chakraborty S, Dasgupta A, Das HN, Singh OP, Mandal AK, Mandal N. Study of oxidative stress in obsessive compulsive disorder in response to treatment with Fluoxetine. Indian $\mathrm{J}$ Clin Biochem. 2009;24:194-7.

40 Denys D, Fluitman S, Kavelaars A, Heijnen C, Westenberg HG. Effects of paroxetine and venlafaxine on immune parameters in patients with obsessive compulsive disorder. Psychoneuroendocrinology. 2006;31:355-60. 